\title{
Tensile strength of solution-spun, ultra-drawn ultra-high molecular weight polyethylene fibres 2 . Influence of propylene comonomer content
}

\author{
Citation for published version (APA): \\ Bastiaansen, C. W. M. (1992). Tensile strength of solution-spun, ultra-drawn ultra-high molecular weight \\ polyethylene fibres 2. Influence of propylene comonomer content. Polymer, 33(8), 1653-1655. \\ https://doi.org/10.1016/0032-3861(92)91062-7
}

DOI:

10.1016/0032-3861(92)91062-7

Document status and date:

Published: 01/01/1992

\section{Document Version:}

Publisher's PDF, also known as Version of Record (includes final page, issue and volume numbers)

\section{Please check the document version of this publication:}

- A submitted manuscript is the version of the article upon submission and before peer-review. There can be important differences between the submitted version and the official published version of record. People interested in the research are advised to contact the author for the final version of the publication, or visit the $\mathrm{DOI}$ to the publisher's website.

- The final author version and the galley proof are versions of the publication after peer review.

- The final published version features the final layout of the paper including the volume, issue and page numbers.

Link to publication

\footnotetext{
General rights

- You may freely distribute the URL identifying the publication in the public portal. follow below link for the End User Agreement:

www.tue.nl/taverne

Take down policy

If you believe that this document breaches copyright please contact us at:

openaccess@tue.nl

providing details and we will investigate your claim.
}

Copyright and moral rights for the publications made accessible in the public portal are retained by the authors and/or other copyright owners and it is a condition of accessing publications that users recognise and abide by the legal requirements associated with these rights.

- Users may download and print one copy of any publication from the public portal for the purpose of private study or research.

- You may not further distribute the material or use it for any profit-making activity or commercial gain

If the publication is distributed under the terms of Article 25fa of the Dutch Copyright Act, indicated by the "Taverne" license above, please 


\title{
Tensile strength of solution-spun, ultra-drawn ultra-high molecular weight polyethylene fibres: 2 . Influence of propylene comonomer content
}

\author{
C. W. M. Bastiaansen* and G. P. Grooters \\ DSM Research, PO Box 18,6160 MD Geleen, The Netherlands \\ (Received 10 December 1990; revised 22 April 1991; accepted 22 May 1991)
}

\begin{abstract}
The effect of copolymerization with propylene on the fracture behaviour of solution-spun ultra-drawn, ultra-high molecular weight polyethylene (UHMW-PE, $M_{\mathrm{w}}>10^{3} \mathrm{~kg} \mathrm{~mol}^{-1}$ ) fibres was investigated. UHMW-PE grades with virtually identical molecular weight and varying comonomer content $(0.5-13.5$ $\mathrm{CH}_{3} / 1000 \mathrm{C}$ atoms ) were used. It is shown that the tensile strength of drawn UHMW-PE fibres, at a constant Young's modulus, is independent of the comonomer content of the polymer. Apparently, the methyl side-groups hardly influence the fracture behaviour of the fibres. In combination with the experimental observation that methyl side-groups decrease intermolecular chain slippage (creep), this indicates that the failure process of solution-spun, drawn UHMW-PE fibres is mainly controlled by chain scission.
\end{abstract}

(Keywords: tensile strength; fibre; propylene)

\section{INTRODUCTION}

In part 1 of this series, the influence of macroscopic dimensions on the fracture behaviour of solution-spun, ultra-drawn ultra-high molecular weight polyethylene (UHMW-PE, $M_{\mathrm{w}}>10^{3} \mathrm{~kg} \mathrm{~mol}^{-1}$ ) fibres was investigated $^{1}$. It was shown that the tensile strength of UHMW-PE fibres, at a constant Young's modulus, is virtually independent of the fibre diameter. Moreover, it was concluded that the failure process of UHMW-PE fibres is controlled by events on a molecular level such as intermolecular chain slippage (creep) and/or chain scission.

Theoretical studies concerning the fracture mechanics of monodisperse, perfectly oriented polyethylenes with a finite molecular weight were performed by Termonia and $\mathrm{Smith}^{2}$. These studies indicated that the failure process of high molecular weight polyethylene fibres is initiated by chain scission. Moreover, it was also shown that the fracture process of perfectly oriented, low molecular weight polyethylene is controlled by intermolecular chain slippage.

An experimental study concerning the molecular mechanism of fracture of UHMW-PE fibres was performed by Smook et al. ${ }^{3}$. The activation energy of fibre fracture was determined, using life-time measurements under static loading conditions, and it was concluded that the failure process of drawn UHMW-PE fibres is controlled by a combination of chain scission and (intermolecular) chain slippage.

In this study an attempt is made to distinguish between two possible molecular mechanisms of fibre fracture, i.e. chain scission and chain slippage (creep). Intermolecular chain slippage in solution-spun, ultra-drawn UHMW-PE

\footnotetext{
* To whom correspondence should be addressed
}

fibres is restricted by using copolymers with an increasing amount of methyl side-groups ${ }^{4-9}$, and the influence on the fracture behaviour is investigated.

\section{EXPERIMENTAL}

The UHMW-PE grades used in this study are listed in Table 1. Special care was taken to select UHMW-PE grades with virtually identical weight average molecular weight $\left(M_{\mathrm{w}}\right)$ and polydispersity $\left(Q=M_{\mathrm{w}} / M_{\mathrm{n}}\right)$.

UHMW-PE was dissolved in decalin at $170^{\circ} \mathrm{C}$ at a nominal concentration of $4 \% \mathrm{w} / \mathrm{w}$. Prior to the dissolution procedure $2 \% \mathrm{w} / \mathrm{w}$ of an antioxidant (di-butyl$p$-cresol) was added to the polymer and the polymersolvent mixtures were degassed at room temperature. After complete dissolution, which took approximately $2 \mathrm{~h}$, the solutions were transferred to a spinning device ${ }^{1}$. Fibres were spun at $170^{\circ} \mathrm{C}$, quenched to room temperature and subsequently dried at ambient conditions.

Drawing of UHMW-PE fibres was performed at $120^{\circ} \mathrm{C}$ on thermostatically controlled hot shoes. The draw ratio was determined by measuring the weight of a fixed length of fibre prior to and after drawing.

Nominal stress-strain curves of drawn UHMW-PE fibres were recorded at room temperature on a Zwick

Table 1 Grades of UHMW-PE used

\begin{tabular}{llll}
\hline Grade & $\begin{array}{l}M_{\mathrm{w}} \\
\left(\mathrm{CH}_{3} / 1000\right.\end{array}$ & $\begin{array}{l}\times 10^{3} \\
\times \text { atoms }\end{array}$ & $\begin{array}{l}\text { Polydispersity } \\
Q\left(=M_{\mathrm{w}} / M_{\mathrm{n}}\right)\end{array}$ \\
\hline 1 & 0.5 & 2.0 & 8 \\
2 & 2.8 & 2.8 & 7 \\
3 & 6.3 & 1.9 & 10 \\
4 & 13.5 & 2.1 & 11 \\
\hline
\end{tabular}


Tensile Tester equipped with fibre clamps. The original length of the fibres was $0.25 \mathrm{~m}$ and a constant crosshead speed of $0.025 \mathrm{~m} \mathrm{~min}^{-1}$ was used.

\section{RESULTS AND DISCUSSION}

The Young's modulus and tensile strength of solutionspun, ultra-drawn UHMW-PE fibres are plotted in Figures 1 and 2 , respectively, as a function of the draw ratio. In accordance with previous studies ${ }^{4-9}$, it is found that copolymerization reduces both the Young's modulus and tensile strength of fibres. Probably, copolymerization with propylene introduces local misalignment in drawn UHMW-PE fibres which reduces the (short-term) mechanical properties.

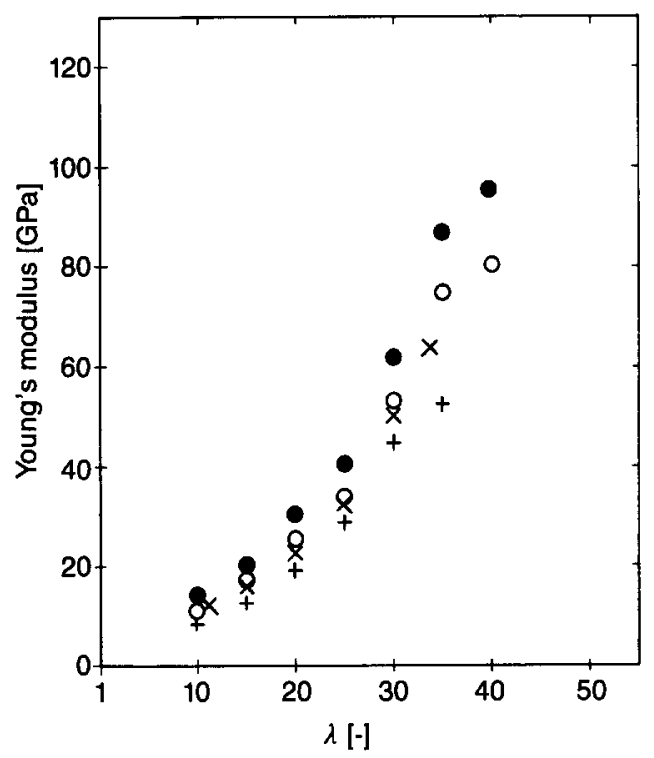

Figure 1 Young's modulus of UHMW-PE fibres as a function of the draw ratio. 9 , Grade $1 ; O$, grade $2 ; \times$, grade $3 ;+$, grade 4

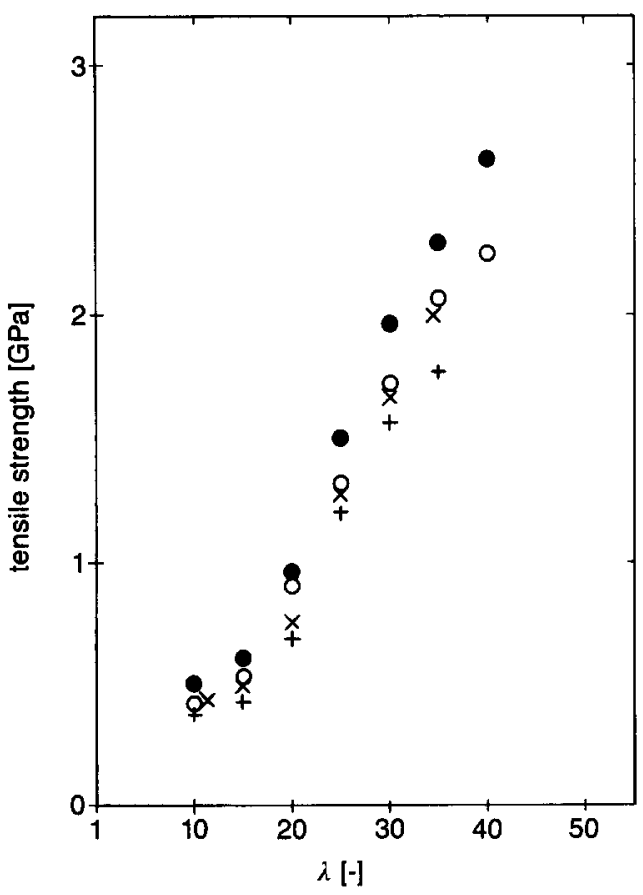

Figure 2 Tensile strength of UHMW-PE fibres as a function of the draw ratio. - Grade $1 ; O$, grade $2 ; \times$, grade $3 ;+$, grade 4

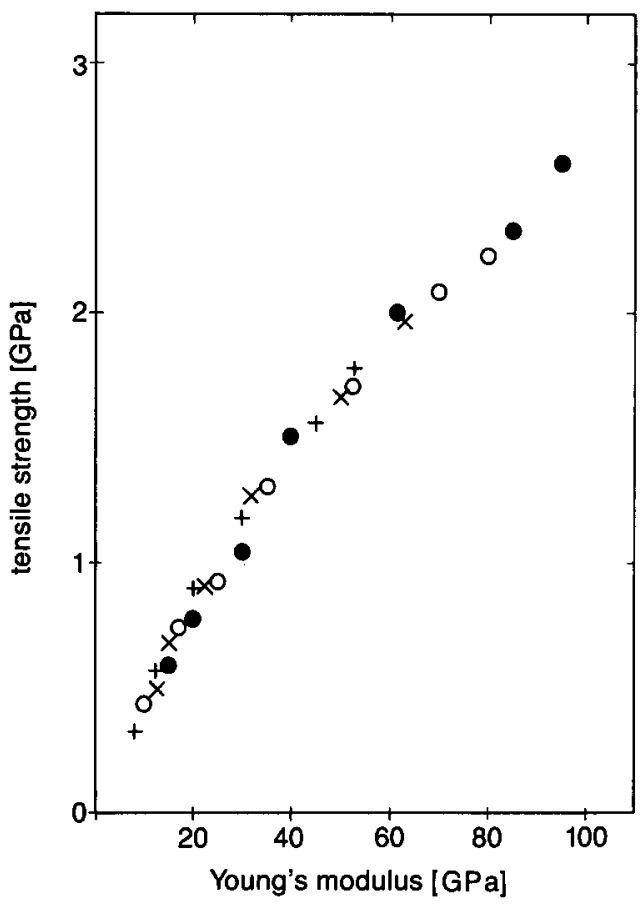

Figure 3 Tensile strength versus Young's modulus of drawn UHMW. PE fibres. Grade $1 ; O$, grade $2 ; \times$, grade $3 ;+$, grade 4

It has previously been shown that the Young's modulus of drawn UHMW-PE fibres is uniquely related to the degree of chain orientation and extension ${ }^{10-14}$. However, the degree of chain orientation and extension also influence the tensile strength. This influence should therefore be eliminated and this can be achieved by comparing the tensile strength of fibres at a constant Young's modulus ${ }^{1,15,16}$.

The tensile strength of copolymerized, drawn UHMWPE fibres is plotted in Figure 3 as a function of the Young's modulus. Fibres with a low Young's modulus $(<20 \mathrm{GPa})$ and a yield point in the stress-strain curve were excluded from this graph ${ }^{1}$. A relationship independent of comonomer content is observed between the Young's modulus and tensile strength. Apparently, copolymerization reduces the Young's modulus and (pseudo-brittle) tensile strength of UHMW-PE fibres to the same extent.

The properties of melt-crystallized and solution-spun, ultra-drawn polyethylene copolymers have been discussed $^{4-9}$ in several studies. It has been shown that the long-term properties of polyethylene fibres can be improved by using polyethylene copolymers. For instance, the creep rate of drawn fibres under static loading conditions, and the yield stress in long-term tensile tests increase with the incorporation of comonomers such as propylene and butene. Apparently, the side-groups introduced into polyethylene by copolymerization severely restrict intermolecular chain slippage and consequently the creep rate decreases.

The well documented experimental observation that copolymerization reduces intermolecular chain slippage can be used to identify the molecular mechanism of fibre fracture in ultra-drawn UHMW-PE fibres. In Figure 3, the tensile strength versus Young's modulus curve of UHMW-PE fibres is shown to be independent of the comonomer content. In other words, reducing intermolecular chain slippage (creep) by copolymerization 
with propylene hardly influences the fracture process of UHMW-PE fibres. Consequently, it is concluded that intermolecular chain slippage plays a minor role in fibre failure. Apparently, the fracture process of drawn UHMW-PE fibres is mainly controlled by chain scission.

It might seem surprising that, at a constant draw ratio, copolymerization simultaneously enhances the (longterm ) yield stress of polyethylene fibres ${ }^{4-9}$ and reduces the (short-term) tensile strength (Figure 2). However, the properties of solution-spun, ultra-drawn UHMW-PE fibres are strongly dependent on the time-scale of testing. This subject will be dealt with extensively in part 3 of this series ${ }^{17}$.

\section{REFERENCES}

1 Bastiaansen, C. W. M. Polymer 1992, 33, 1649

2 Termonia, Y. and Smith, P. in 'High Modulus Polymers' (Eds
A. E. Zachariades and R. S. Porter), Marcel Dekker, New York, 1988, Ch. 11

3 Smook, J., Hamersma, W. and Pennings, A. J. J. Mater. Sci. 1984, 19, 1359

Meinel, G. and Peterlin, A. Eur. Polym. J. 1979, 7, 657

Wilding, M. A. and Ward, I. M. Polymer 1981, 22, 871

Wilding, M. A. and Ward, I. M. Plast. Rubber Process. Applic. $1981,1,167$

7 Capaccio, G. and Ward, I. M. J. Polym. Sci., Polym. Phys. Edn. 1984, 22, 475

8 Seguela, R. and Rietsch, F. Eur. Polym. J. 1984, 20, 765

Seguela, R. and Rietsch, F. Polymer 1986, 27, 532

Capaccio, G. and Ward, I. M. Nature Phys. Sci. 1973, 243, 143

Ward, I. M. Polym. Eng. Sci. 1984, 24, 724

Irvine, P. A. and Smith, P. Macromolecules 1986, 19, 240

Postema, A. R. and Smith, P. Polymer 1989, 30, 2332

Postema, A. R. and Smith, P. Macromolecules submitted

Smith, P., Lemstra, P. J. and Pijpers, J. P. L. J. Polym. Sci., Polym. Phys. Edn. 1982, 20, 2229

16 Smith, P. and Lemstra, P. J. J. Polym. Sci., Polym. Phys. Edn. 1981, 19, 1007

17 Bastiaansen, C. W. M. Polymer submitted 